\title{
The Pedagogy of Tact in Theoretical Discourse
}

Keith Doubt

Northeast Missouri State University

\section{Introduction}

This paper provides a critical interpretation and a supportive analysis of Hans-Georg Gadamer's concept of tact and the role that it plays in the conceptual thinking of human science. For Gadamer tact represents a compellingly open and significantly noncritical way of knowing the human subject. The concept is very important to Gadamer explicitly in the first section of Truth and Method and implicitly throughout his other works on philosophical hermeneutics (Gadamer, 1986a, pp. 5-39).

The particular way I examine this subject is by raising the question of what is "good" about tact and what is good about tact with respect to the theoretical discourse of human science. My choice of this approach is reinforced by Gadamer's (1986b) recent publication of The Idea of the Good in Platonic-Aristotelian Philosophy where he endorses the Platonic belief in the Good as the highest notion on which all others depend:

But in the end it becomes fully clear that only looking to what is good ... or what is better or best, respectively, promises him real knowledge, or, as we would say, "understanding"-understanding of the universe as well as the polis and the psyche. (pp. 25-26)

My argument is that the goal of tactful interpretation in the human sciences is to develop that human consciousness that can distinguish dialectical discourse from sophism. Although tact itself does not generate an inquiry that is dialectical and although tact itself often seems to be just a matter of sophism, what is good about tact is that it seeks to distinguish between these two modes of discourse and encourages the inquiry that is dialectical. Gadamer (1986b) states, "Where the subject is of the greatest importance, that is, in the realm of dialectic, one is threatened steadily by the danger of sophism" (p. 99). The pedagogy of tact, I argue, is to combat a mode of discussion where "one succumbs to the blind desire for success in contentious argument" (p. 118). 


\section{The Concept of Tact}

Gadamer's work has been criticized for being antimethodological (Hirsch, 1967; Rorty, 1979), but Gadamer's account of the concept of tact and its particular role in theoretical analysis implicitly provides for that methodology that sustains the work of hermeneutical phenomenology. For Gadamer, tact points to the way in which the inquiry of human science supersedes the epistemological constraints of the natural sciences and of social science as natural science. Gadamer (1986a) states:

To do justice to the human sciences, he [Helmholz] emphasized memory and authority and spoke of the psychological tact that here replaced the conscious drawing of inferences. What is the basis of this tact? Does what is scientific about the human sciences not lie rather here than in its methodology? [italics added] (p. 9)

While Gadamer praises Helmholz for introducing the concept of tact to the discussion of human inquiry, he criticizes him for not going far enough. To Gadamer, the problem with Helmholz's formulation of tact is that it does not depict tact as anything more than an artistic intuition or a "purely psychological insight." To Gadamer, tact is rather a mode of being that not only adequately but also justifiably replaces the necessity for any "methodological" control of human science. Gadamer (1986a) says, "By 'tact' we understand a particular sensitivity and sensitiveness to situations and how to behave in them, for which we cannot find any knowledge from general principles" (p. 16). Still more strongly, tact is the control or, let us say, discipline that is most necessary for the successful development of human inquiry. Gadamer (1986a) says:

Hence an essential part of tact is its inexplicitness and inexpressibility. One can say something tactfully; but that will always mean that one passes over something tactfully and leaves it unsaid, and it is tactless to express what one can only pass over.

(pp. 16-17)

Gadamer's thesis is provocative, and it is what Habermas (1983) is perhaps thinking of when he disparagingly refers to Gadamer's work as "the gentlemen's concept of hermeneutics" (p. 269). Gadamer elevates the concept of tact above its everyday understanding. He presents the idea of tact as a self-justifying epistemology; that is, tact suggests an ontology, a humanistic conception of what is real in social discourse, to which, Gadamer (1986a) says, every methodology ought to be subject. 
Gadamer's discussion of tact often takes place on two levels. Primarily, he speaks of tact as a way to name an ontology to which the work of philosophical hermeneutics is committed, and I develop this matter throughout the paper. Gadamer also speaks of tact as a behavior: an ideal type of ethical behavior for every human scientist. Gadamer (1986a) states, "Tact helps one to preserve distance, it avoids the offensive, the intrusive, the violation of the intimate sphere of the person" (p. 17). We ask, is this type of behavior necessary for the work of human science and is it necessarily good for the work of human science? How does the human scientist, by preserving distance, avoiding the intrusive and the violation of the intimate sphere of the person, come to understand in a better way his or her subject?

The argument that tact could represent a compelling foundation for the conduct of human inquiry provokes many contemporary theorists. Sartre (1965) states his resistance to the idea when he incisively writes:

Thus to act "with tact" implies that the doer of the act has adopted a certain conception of the world, one that is traditional, ritual, and synthetic; one for which he can give no reason. It implies also a particular sense of psychological ensembles, it is in no sense critical, and we might add that it takes on its whole meaning only in a strictly defined community with common ideas, mores, and customs. (p. 124)

Sartre's comment about the limited nature of the tactful actor's self-consciousness makes it challenging for us to recover what is good about tact in theoretical discourse, but, as indicated, the concept is extremely important to Gadamer for the work of philosophical hermeneutics and so important to us for the appreciation of Gadamer's work.

The pedagogy of Gadamer's inquiry is to help his readers to acquire and possess a sense of tact, and yet Gadamer (1986a) will also describe this form of being as "this right, unlearnable, and inimitable tact that bears the judgment and mode of knowledge of the human sciences" (p. 15). We ask, how can one acquire this tact when it is also unlearnable and inimitable? Although actually speaking of Schleiermacher's concept of hermeneutics, Sica (1981) would articulate this criticism of Gadamer's presentation this way: "It smacks of an aristocratic, hermetic definition of knowing" (p. 46).

There are, of course, theorists who argue that their methodology is unlearnable as a techne. That is, there is no rule that in itself adequately accounts for or reproduces the procedure of their inquiry. But these theorists seldom go so far as to state, as 
Gadamer does, that their inquiry is inimitable, that is, unteachable. On this issue, Blum (1970) writes:

It will probably be recognized that I have nowhere provided rules for theorizing and, of course, it is an essential feature of my description of theorizing that this be impossible.... How, then, does one learn theorizing? I would say that one "gets the hang of it" by watching someone theorize (or re-cover his theoretic language) on a variety of particular examples. (p. 319)

The rhetoric of Gadamer's presentation of tact is problematic. Basically, the concept is overloaded in that it does more work than it actually seems capable of doing. Gadamer does not critically locate the limit of tact and examine what is good about tact in itself. Rather, he exaggerates the significance of the concept, and this is a practice of which Gadamer (1986a) himself is highly critical. "We cannot avoid thinking about that which was unquestionably accepted, and hence not thought about, by an author, and bringing it into the openness of question" (p. 337). Here Gadamer is providing us with the incentive for the study of his own work.

\section{Tact and Theoretical Discourse}

One of the problems of sophism is that it fails to communicate the significance of its subject, and one way it does this is by exaggerating the significance of its subject to the point that its significance is no longer recognized. In contrast, dialectical inquiry seeks to disclose the significance of its subject, and the way it seeks to do this is by addressing the limit of its subject and the necessity and the good of that limit for the understanding of that subject.

Habermas (1985) addresses this point when he writes, "Hermeneutical consciousness is incomplete so long as it has not incorporated into itself reflection on the limit of hermeneutical understanding" (p. 302). But Habermas more or less makes this criticism of every subject and author that he examines (Blum \& McHugh, 1984, p. 96), which is perhaps why Gadamer (1985) responds to Habermas's criticisms by asking whether this guiding light of the emancipatory consciousness is not perhaps "the vision of an anarchistic utopia" (p. 291). Habermas and Gadamer both speak to the need to defend the discourse of the human sciences from the threat of sophism, and yet each accuses the other of failing to defend adequately against this threat. "This sophistic dialectic," Gadamer (1986b) notes, "is not real thinking, for in pursuing it one succumbs to the blind desire for success in contentious argument" (p. 118). 
In The Idea of the Good in Platonic-Aristotelian Philosophy Gadamer (1986b) argues that there is an important and clear advantage in raising the question of the good and the question of the good of a particular subject. Gadamer carefully explicates the Platonic-Aristotelian theory of inquiry in these terms and wishes to renew this theory within the context of contemporary human inquiry. Gadamer is perhaps at his best when he discusses Plato, and he is not alone in taking the position he does. Blum (1978) presents a comparable reading of the relation between Plato and Aristotle when he writes:

One conventional way of understanding Aristotle leads to the conclusion that the first decisive enemy of Socrates was Aristotle. Yet, if we tentatively suspend our inquest into this opinion, we might still begin with a remark of Aristotle with which Socrates is sure to agree. In the Ethics Aristotle says, "Every art and every inquiry, and similarly every action and pursuit, is thought to aim at some good; and for this reason the good has been rightly declared to be that at which all things aim." (p. 1)

In the same vein, Gadamer (1986b) starts his study:

Today it is an established fact that in the entire traditional Aristotelian works we never get back to a point where Aristotle was not a critic of Plato's doctrine of the ideas, but also that we never arrive at a point where he really ceased to be a Platonist. (p. 8)

Notice that Blum and Gadamer begin by expressing a compellingly open and importantly nonjudgmental relation toward Aristotle and his relation to Plato. Both express good will toward Aristotle's theorizing and Aristotle's theorizing vis-à-vis Plato. For instance, Gadamer (1986b) does not begin, as he could have begun, with the critical and sensational remark that "Aristotle ignored Plato's self-criticism and cold-bloodedly repeated Plato's critical arguments in his own critique of Plato" (p. 9).

Gadamer (1986b), in other words, does not accuse Aristotle of acting in bad faith, and yet Gadamer is sensitive to this possibility. Blum and Gadamer slip by the worst readings of Aristotle's work vis-à-vis Platonic philosophy, and their tactfulness, whether it is gentlemanly or not, accounts for the excellence of their theoretical studies. Speaking of tactfulness and its importance to the development of theoretical discourse, Gadamer (1986a) states, "But to pass over something does not mean to avert the gaze from something, but to watch it in such a way that rather than knock against it, one slips by it" (p. 17).

What is the pedagogy of tact in theoretical discourse? We begin to see that tact involves setting aside a purely critical opinion, 
that is, an opinion that "knocks"; such an opinion is not constructive to a truly meaningful discussion, that is, a discussion that understands. Tact instead focuses on the positive content of a subject: how a subject orients to the question of what is good as an essential feature of what that subject is. Aristotle's statement "Every art and every inquiry, and similarly every action and pursuit, is thought to aim at some good" is the guiding ontology for Platonic-Aristotelian inquiry. The idea of tact, Gadamer (1986a) says, is the contemporary way in which modern theorists exemplify Aristotle's Socratic procedure for the development of theoretical inquiry. Here is Gadamer's methodology no matter what the context, and it is the significant one for the meaningful development of theoretical discourse in all the human sciences.

\section{The Interactional Concept of Tact}

I noted that Gadamer (1986a) sometimes speaks of tact as a behavior, a sort of ideal type of behavior for every social scientist, and I felt uncomfortable with this idea. When Gadamer speaks of tact in this way, he begins to gloss the idea of what tact really is. To generate a sharper analysis of tact I draw on the early work of Goffman (1967) and in this way make what Gadamer (1986a) might call an application: "We consider application to be as integral a part of the hermeneutical act as are understanding and interpretation" (p. 275).

In his seminal study of "face-work," Goffman provides a fairly definitive formulation of what tact is on an interactional level. When Goffman focuses on the interactional practices of tact, he captures analytically what Gadamer says of tact.

"Face," Goffman (1967) says "is the positive social value that a person claims for himself" (p. 5) and "to be out of face" is to be caught in a social interaction where your positive social value, your line, image, history, reputation, that is, the positive knowledge of you that others as well as you share, is at risk or seriously called into question. As a theory for the ground rules of interpersonal interaction, Goffman's face-work accounts for our willingness to save not only our own face, but also (and more importantly) the face of another. Tact is our ability and willingness to preserve the positive social value not of ourselves, but of another social member. Goffman (1967) says:

One can say that to give face is to arrange for another to take a better line than he might otherwise have been able to take, the other thereby gets face given to him, this being one way in which he can gain face. (p. 9) 
To illustrate, recall how Blum (1978) and Gadamer (1986b) both arrange for Aristotle to take a better line with respect to Plato than perhaps Aristotle himself could arrange. Blum and Gadamer are doing face-work; they formulate Aristotle's work in a compelling way by showing good will toward Aristotle, and, interestingly, the way in which they show good will toward Aristotle is by stressing Aristotle's good will toward Plato even when there seems to be little evidence for this assumption. Is this sophism?

Like Sartre (1965) earlier, Goffman (1967) is skeptical of such tactful behavior in social discourse, and his skepticism, whether we agree with it or not, helps us to analyze the idea of tact in a constructive rather than in an unconditional way. How is it that, when we arrange for another to take a "better" line, we do not in fact patronize the other? How is it that, when we help another regain a more positive social value, we do not take on the role of the superior? On what basis do we decide what is a better line for another to take? What makes a better line better? Is it better with respect to the other per se (altruism)? Is it better with respect to ourselves and our advantage (egoism)? Is it better with respect to the preservation of social order and a sense of interactional harmony (conformity)? Or is it better with respect to some metaphysical principle of what is just or what is good (Socratic irony)? As an empirical scientist, Goffman (1967) himself needs to suppress this last possibility as a real one, and so he writes:

Perhaps the main principle of the ritual order is not justice but face, and what any offender receives is not what he deserves but what will sustain for the moment the line to which he has committed himself, and through this the line to which he has committed the interaction. (p. 44)

Goffman (1967) argues that there can be a multis of motives for doing tact, but, as theorists examining what tact in itself is, we need to recover how this multis of motives can collectively account for what tact is. Think of how Socrates limits Meno's attempt to define virtue. Rather than provide a list of an infinite number of motives for being tactful (egoism, flattery, condescension, teaching, patronizing, nurturing, altruism, conformity, irony, and sarcasm), we need to discipline our narrative by looking to what is good about tact: how tact in itself aims at what is good.

In this light it is useful to focus on a seemingly weak motive for doing tact so as to recover what is essential to tact in itself. Goffman (1967) indicates that the rationality for the tactful 
behavior is basically utilitarian. Think, for example, of the diplomat who is held captive by a group of terrorists. Prudently, the diplomat chooses to be tactful with the terrorists. Here tact is a mode of survival: It provides the only way for the diplomat to defend himself or herself against the terrorists' likely aggression. By being tactful, by giving the terrorists' politics, conditions, and needs a favorable line, the diplomat hopes to influence the terrorists. He or she hopes to create something of a social contract between himself or herself and the terrorists, something that would make them think twice about whether acting violently toward someone who might be their ally is to their advantage. Goffman's work suggests that tact is nothing more than the exemplification of the Hobbesian social contract at the microlevel.

The tension in this formulation is that tact looks either overly calculative or else perhaps too humanistic; that is, a gentle and submissive way of influencing another as well as of being influenced. Here tact is but a hollow means to an end where the end is survival within any given social community. The diplomat shows tact by expressing sympathy and support for the terrorists' cause, but is this tactfulness ever principled or genuine? Does the diplomat really have sympathy for the terrorists' cause, or is his or her expression of sympathy simply expedient? With these questions, we seek to grasp the limit of tact through an examination of its actual practices.

The critically practical question at this point (the one that requires our use of practical reason) is if tact is the best way of influencing the barbarian, the brute, or the bully. On this matter Gadamer (1986a) himself writes:

Whoever abandons himself to his particularity is ungebildet [unformed], e.g., if someone gives way to blind anger without measure or sense of proportion. Hegel shows that basically such a man is lacking in the power of abstraction. (p. 13)

Let us reformulate this point because there is something misleading here. The barbarian is abstract about his or her particularity because the barbarian treats his or her particularity as if it were what is universal, and in this way the barbarian lacks the power of abstraction. But, despite what Gadamer says about Hegel, Hegel is not against particularity per se, and Gadamer is confusing us when he tells us that Hegel is. The power of abstraction involves the theoretical movement from the particular to the universal as well as from the universal to the particular. The power of abstraction is dialectical. In Blum and McHugh's (1984) words, "the ultimate truth is subject to 
discourse (its majesty must be adapted to human needs of grasping and expressing)" (p. 143).

Notice that the sophist, Gadamer's antagonist, is but the other side of the coin to the barbarian. The barbarian is unformed (ungebildet); the sophist is overformed (übergebildet). If the barbarian lacks the power of abstraction, the sophist abuses the power of abstraction, where this is to feign indifference to the question of what is good. The sophist abuses the power of abstraction by moving every particular to the universal. The sophist fails to show how the universal itself needs the particular, in other words- "its majesty must be adapted to human needs of grasping and expressing."

We now see how, through the concept of tactfulness, Gadamer shows concern for the use of abstraction in theoretical discourse. Through the concept of tactfulness Gadamer (1986b) speaks to how the human scientist exercises reserve toward abstraction in human inquiry. Gadamer writes, "for Plato the dialectician does not possess some superior art, which he employs in self-justification, but that, instead, he seeks real justification" (p. 38).

\section{Socrates' Use of Tact}

Let us now consider the classic example of this use of tact, one that brings together our theoretical and interactive analysis. In Book One of the Republic why does Socrates keep saying to the contentious and bullying Thrasymachus such things as "That's because you are wise Thrasymachus," "You best of men," or "My blessed Thrasymachus"? It seems obvious that Socrates is neither sincere nor genuine in making these statements. What is the good reading of these statements? Are they vacuous fillers? If so, why are they there?

For Socrates the best way to relate to Thrasymachus's angry, insulting behavior is to be tactful. Socrates' phrases sound hollow, but they serve a function. Socrates seeks some semblance of a conversation in this contentious discussion with Thrasymachus. The reason that their interaction does not deteriorate into chatter, the consequence of sophism, is because Socrates feigns a degree of tactfulness. With tact Socrates provides Thrasymachus with a better line, a more rational line, with respect to the question of what is just, and this use of tact pays off. Blum and McHugh (1984) note:

A stronger notion of implication was developed by Socrates in the exchange with Thrasymachus, when he showed justice to be good by implication through his demonstration of how justice could 
not (essentially) be as it was reputed to be in various opinions. (p. 140)

Socrates' tact influences Thrasymachus to stay with the discussion of justice. Socrates says, "Thrasymachus, you demonic man, do you toss in such an argument, and have it in mind to go away before teaching us adequately or finding out whether it is so or not?" The line that Socrates provides Thrasymachus is for Thrasymachus to teach Socrates the benefit of injustice, a very exciting possibility for Thrasymachus. But does Socrates really want Thrasymachus to teach him this? The advantage of tact is that, by providing another with a more acceptable line, it establishes some order within the discussion, even if this order is an artificial one. In providing for some order the tactful response establishes an opportunity for a meaningful discussion or what Gadamer (1986a) has spoken of as "the fusion of horizons." Although tact per se does not represent that conversation (any tyrant can be tactful and most know how to be), it nevertheless provides a bridge for that conversation that represents a fusion of horizons (Dostal, 1987, p. 433).

The critical question here for those of us who are examining what is good about tact is if there is a difference between what we could call being "cagey," which is Thrasymachus's charge against Socrates' narrative, and being tactful. At times Socrates' tactfulness seems to be mocking and sarcastic, which, of course, invites contentiousness. One way to interpret the subsequent speeches of Glaucon and Adeimantus in Book Two of the Republic is that Glaucon and Adeimantus are asking Socrates how he does not just happen at this particular time and on this particular occasion to be more clever than Thrasymachus (i.e., superior in refuting another). At another time someone like Thrasymachus will come along, outfox even Socrates, and so prove himself to be a better sophist. Does saying that Socrates is charismatic mean that his arguments for the benefits of justice vis-à-vis injustice are necessarily the most persuasive (Gadamer, 1986b, p. 51)? Where is the necessity of justice? Does that necessity lie simply within the character of Socrates? The speeches of Glaucon and Adeimantus in Book Two influence Socrates to try another role; that is, Socrates has reached his limit with them. And, in having to take another role, Socrates develops as a dialectician. Socrates' subsequent inquiry is informed by practical reasonableness or phronesis, and we could say that, in developing as a dialectician, Socrates becomes more of a social theorist and less of a philosopher. Gadamer (1986b) states: 
The new role that Socrates plays in the discussion of the just state [in the Republic], for instance, should, and must, be perceived as a clearly accentuated change ... it is of particular significance that Plato's brothers are the ones who make the transition with Socrates in the discussion of book 2 of the Republic. (pp. 2223)

The problem that arises when an actor's tactfulness is perceived as self-serving, for example, merely as a means to setup and refute an opponent, is that suspicion develops, "No answer is found to the question posed" (Gadamer, 1986b, p. 22). The listener becomes distrustful of the speaker's good will, which is the basic issue for the hermeneutics of suspicion (Gadamer, 1984; Ricoeur, 1981). According to the hermeneutics of suspicion, to distrust the good will of the speaker is the beginning of critical, albeit skeptical, insight. This, of course, is counterproductive to the deeper interests of tact. Tact wants to encourage listening because listening is essential to conversation. And the way tact encourages listening is by demonstrating its own ability to listen. By showing its willingness to listen, that is, to listen to how another speaker orients to the question of what is good, tact develops a sense of confidence within social discourse where this confidence provides the basis to transform discourse into conversation.

Notice here how the sophist actually influences a listener not to listen. The sophist influences his or her listener to distrust the good will of the speaker where such is represented in the speaker's concern for the question of what is good. For the sophist to be able to distrust the good will of the speaker and to show another how to distrust the good will of a speaker represents a theoretical insight that is powerful. Notice how the sophist's rhetoric belies his or her very own talk.

Tact, in contrast, influences the listener to heed the good will of the speaker, even when this good will is not at all apparent. And here is what is so gentlemanly about tact. Tact assumes the good will of the speaker, that is, his or her interest in the question of what is good, even when this assumption about the speaker seems to be poorly grounded. Tact makes a commitment to the assumption of another's good will, not necessarily for the sake of the other and not necessarily for the sake of oneself, but for the sake of that human conversation that inquires.

\section{Conclusion}

Given this analysis, it is worth commenting by way of conclusion on the recent publication of the Gadamer-Derrida debate 
on contemporary human inquiry titled Dialogue and Deconstruction: The Gadamer-Derrida Encounter (Gadamer, 1989). A striking feature of this problematic exchange is that Derrida denies the significance of good will for contemporary inquiry and Gadamer has difficulty responding. Derrida (1989) says, "I am not convinced that we ever really have this experience that Professor Gadamer describes, of knowing in a dialogue that one has been perfectly understood" (p. 54). And Gadamer (1989) replies:

I cannot believe that Derrida would actually disagree with me about this. Whoever opens his mouth wants to be understood; otherwise one would neither speak nor write. (p. 55)

I have argued that to show tact is to ask how another orients to the question of what is good, and there is every reason to continue to use this method in our reading of Derrida's provocative remarks toward Gadamer. How does Derrida's (1989, pp. 58-71) address "Interpreting Signatures (Nietzsche/Heidegger): Two Questions" orient to the question of what is good?

The answer at first glance is deceptively simple. What is compelling about Derrida's (1989) remarks is that Derrida displays a knowledge of Nietzsche's work that seems superior to Heidegger's understanding of Nietzsche's work. An important question, then, is how is it that Heidegger failed to know Nietzsche in an authentic way? Derrida (1989) provides an interesting answer; he says that Heidegger's relation to Nietzsche is primarily one of good intention, and this relation accounts for the flaw in Heidegger's appreciation of Nietzsche.

In saving Nietzsche, Heidegger loses him too; he wants at the same time to save him and let go of him. At the very moment of affirming the uniqueness of Nietzsche's thinking, he does everything he can to show that it repeats the mightiest (and therefore the most general) schema of metaphysics. (p. 65)

What Derrida wants his reader to see is that with an absolutely metaphysical friend like Heidegger, who needs a particular enemy? The implicit claim here is that Derrida is Nietzsche's better friend-Derrida knows Nietzsche as a unique entity. Derrida's remarks are defending Nietzsche as not being what Heidegger reputes him to be. Notice, though, that this claim to a deeper friendship infers that Derrida himself embodies more good will toward the subject.

For Derrida (1989), Heidegger's good intentions are fatal to the genuine spirit of Nietzsche. In the following passage, Derrida makes this point poignantly: 
These are the preliminary remarks ... for a future reading of Heidegger's Nietzsche-for this ambiguous life-saving act, in the course of which one stretches out the net for the tightrope walker, the one who runs the greatest risk overhead on the narrow rope, only in so far as one has made sure that he ... will not be taking any risks. In other words: he was dead before he landed in the net. (p. 69)

Here Nietzsche is the tightrope walker who runs the greatest risk, and Heidegger is the cautious one who stretches out the net.

The idea that animates my reading of Derrida's remarks (for Gadamer) on Heidegger's relation to Nietzsche is that Gadamer's talk $(1989$, p. 55), for perhaps rhetorical reasons, glosses the distinction between good will and good intentions. And Derrida, for analytic reasons, uses Gadamer's gloss critically. Derrida's resistance to the recommendation to heed the importance of good will in contemporary inquiry is grounded in Derrida's own knowledge of what good will really is vis-à-vis what good intentions actually are. Derrida will not defer to good intentions.

Good intentions are fundamentally narrow-minded: They express nothing more or less than a will to power in that they stipulate the needy and helpless character of the subject. Good intentions define what is good for the other in terms of what the other per se is unable to do for himself or herself. Gadamer (1989) says, "one seeks to strengthen the other's viewpoint so that what the other person has to say becomes illuminating" (p. 55).

The limit of good intention is that, if it were not for the ascribed weakness of the other, good intentions would have neither a real place nor a genuine purpose in human discourse. Good intentions are parasitic: They take advantage not of the host's strengths, but of the host's weakness. By suggesting that Nietzsche is not as weak as Heidegger claims, Derrida (1989) undermines and so deconstructs Heidegger's restrictive relation to Nietzsche.

In contrast to good intentions, good will is directed toward the positive content of the other. Good will is not directed toward what the other lacks, but directed toward what the other hasthe other's character, the other's knowledge of self. Although the relation of good will is not in itself what friendship is, it forms the basis for friendship, and, without good will as the prerequisite, friendship cannot develop. What good will does is 
heed what is essential to another's life. Derrida (1989) himself admits:

Life does have a beyond, but it does not allow itself to be made into something secondary. As itself and in itself it unfolds the movement of truth or knowledge. It is in itself as its own beyond.

(p. 66)

Such is the profundity of good will; Derrida's work exemplifies good will toward life, and, in the above passage, he perfectly accounts for its guiding principle in human inquiry. A tactful inquirer recovers how a human life, no matter how different from the inquirer's, orients to the question of what is good as what is essential to that life per se, and to recover this orientation generates understanding.

\section{References}

Blum, A. (1970). Theorizing. In J. Douglas (Ed.), Understanding everyday life (pp. 301-319). Chicago: Aldine.

Blum, A. (1978). Socrates. London: Routledge \& Kegan Paul.

Blum, A., \& McHugh, P. (1984). Self reflection in the arts and sciences. Atlantic Highland, NJ: Humanities.

Derrida, J. (1989). Interpreting signatures (Nietzsche/Heidegger): Two questions. In D.P. Michelfelder \& R.E. Palmer (Eds.), Dialogue and deconstruction: The Gadamer-Derrida encounter (pp. 58-71). Albany, NY: State University of New York Press.

Dostal, R. (1987). The world never lost: The hermeneutics of trust. Philosophy and Phenomenological Research, XLVII(3), 413-433.

Gadamer, H.-G. (1984). The hermeneutics of suspicion. In G. Shapiro \& A. Sica (Eds.), Hermeneutics: Questions and prospects (pp. 54-65). Amherst, MA: University of Massachusetts Press.

Gadamer, H.-G. (1985). The historicity of understanding. In K. Meuller-Vollmer (Ed.), The hermeneutics reader (pp. 274-291). New York: Continuum.

Gadamer, H.-G. (1986a). Truth and method. New York: Crossroad.

Gadamer, H.-G. (1986b). The idea of the good in PlatonicAristotelian philosophy (P.C. Smith, Trans.). New Haven, CT: Yale University Press.

Gadamer, H.-G. (1989). Reply to Jacques Derrida. In D.P.

Michelfelder \& R.E. Palmer (Eds.), Dialogue and deconstruction: The Gadamer-Derrida encounter (pp. 55-57). Albany, NY: State University of New York Press.

Goffman, E. (1967). Interaction ritual. New York: Pantheon.

Habermas, J. (1983). Interpretative social science vs. hermeneutics. In H. Haan, R.N. Bellah, P. Rabinow, \& W.M. Sullivan (Eds.), Social science as moral inquiry (pp. 251-269. New York: Columbia.

Habermas, J. (1985). On hermeneutics' claim to universality. In K. Meuller-Vollmer (Ed.), The hermeneutics reader (pp. 294-319).

New York: Continuum. 
Hirsch, E. (1967). Validity in interpretation. New Haven, CT: Yale University Press.

Ricoeur, P. (1981). Paul Ricoeur: Hermeneutics and the human sciences (J.B. Thompson, Trans.). Cambridge, UK: Cambridge University Press.

Rorty, R. (1979). Philosophy and the mirror of nature. Princeton, NJ: Princeton University Press.

Sartre, J.-P. (1965). Anti-Semite and Jew (G.J. Becker, Trans.). New York: Schocken Books.

Sica, A. (1981). Hermeneutics and social theory. Current Perspectives in Social Theory, 2, 39-54. 